\title{
Response to interferon $\alpha$ treatment and disappearance of cryoglobulinaemia in patients infected by hepatitis $C$ virus
}

P Cresta, L Musset, P Cacoub, L Frangeul, D Vitour, T Poynard, P Opolon, D-T Nguyen, F Golliot, J-C Piette, J-M Huraux, F Lunel

\begin{abstract}
Background-Mixed cryoglobulinaemia is closely associated with hepatitis $\mathrm{C}$ virus (HCV) infection.

Aim-To assess in a prospective open study the efficiency of interferon $\alpha$ treatment of cryoglobulinaemia, as reflected by the disappearance of cryoglobulins and clinical manifestations of the disease, and to analyse the factors predictive of a response to interferon.

Method-Eighty seven consecutive patients with chronic hepatitis $\mathbf{C}$ treated for the first time with interferon at a dose of 3 $\times 10^{6}$ international units three times a week for six months were studied. Forty three patients had cryoglobulins, which were responsible for clinical manifestations in 12.
\end{abstract}

Laboratoire de Bactério-Virologie, CHU Angers, Angers, France

P Cresta

D Vitour

F Lunel

Service

d'Immunochimie, Groupe Hospitalier Pitié-Salpêtrière,

75651 Paris Cedex 13, France

L Musset

Service de Médecine Interne

$P$ Cacoub

J-C Piette

Laboratoire de Bactério-Virologie L Frangeul

J-M Huraux

Service d'HépatoGastroentérologie T Poynard

P Opolon

Service de Santé Publique

D-T Nguyen

F Golliot

Correspondence to: Professor F Lunel, Service de Bactério-Virologie, CHU Angers, 4 rue Larrey, 49033 Angers Cedex, France.

Accepted for publication 25 January 1999
Results-At the end of interferon treatment, cryoglobulins had disappeared in $39 \%$ of the patients. A clinical improvement (except for neuropathies) was observed in all patients. Six months after interferon treatment was stopped, the same rate of response (normal alanine aminotransferase values and undectable HCV RNA) was observed in patients with or without cryoglobulins. Only $14 \%$ of patients still had undetectable cryoglobulins, and all of them also had undetectable serum HCV RNA. The disappearance of cryoglobulins was found less frequently in patients with clinical symptoms than in asymptomatic ones, but the difference was not significant. Sustained responders were more often men, infected by genotype 2 or 3 , with a lower pretreatment viral load.

Conclusion-The presence of cryoglobulins does not seem to affect the response to interferon in HCV infected patients. The improvement in cryoglobulinaemia is strongly associated with a virological response, reinforcing the hypothesis of a direct role for $\mathrm{HCV}$ in the pathogenesis of this disease.

(Gut 1999;45:122-128)

Keywords: hepatitis C virus; chronic hepatitis C; cryoglobulinaemia; cryoglobulins; interferon.

Mixed cryoglobulinaemia is an immunological disorder characterised by the presence of serum immune complexes (generally including a rheumatoid factor) that precipitate at low temperature. Extrahepatic manifestations-for example, purpura, cutaneous vasculitis, arthralgia, glomerulonephritis, and peripheral neuropathy, are often associated. ${ }^{12}$ These circulating cryoglobulins usually include monoclonal and polyclonal components (type II) or only polyclonal components (type III) according to Brouet's classification. ${ }^{3}$

The link between mixed cryoglobulinaemia and liver diseases has been known for many years, but its pathophysiological significance is unclear. ${ }^{145}$ Many authors have reported a high prevalence of hepatitis $\mathrm{C}$ virus (HCV) infection in patients with mixed cryoglobulinaemia. ${ }^{6-10}$ The detection of anti-HCV antibodies and high concentrations of HCV RNA in the cryoprecipitates $^{81011}$ pointed to a possible role for HCV in the pathogenesis of mixed cryoglobulinaemia. Since 1986, several controlled trials have shown that treatment with interferon $\alpha$ is beneficial in chronic non-A, non-B, or $C$ hepatitis. ${ }^{12-15}$ About $50 \%$ of patients treated with interferon $\alpha$ at a dose of $3 \times 10^{6} \mathrm{IU}$ three times a week for six months have normal alanine aminotransferase (ALT) levels at the end of treatment. However, when treatment is discontinued, clinical and virological reactivations are observed in more than half of the patients who respond to interferon. Before the aetiological role of $\mathrm{HCV}$ in mixed cryoglobulinaemia was suspected, corticosteroids, immunosuppressive agents, and plasmapheresis were used to control mixed cryoglobulinaemia disease activity. However, these treatments often failed to achieve definite successful results. Several studies have suggested that interferon $\alpha$ or association of corticosteroids with the interferon $\alpha$ regimen can attenuate the clinical manifestations of mixed cryoglobulinaemia and considerably reduce cryoglobulin production, especially as a close link between HCV and mixed cryoglobulinaemia has also been shown. ${ }^{16-21}$

In this study we compared the efficiency of interferon $\alpha$ treatment in 87 consecutive patients with chronic hepatitis $\mathrm{C}$, with and without cryoglobulins, and tried to assess the relation between the biochemical (ALT) and virological (HCV RNA) responses to interferon and the disappearance of cryoglobulins. The role of the different factors (severity of liver disease, HCV genotypes, HCV RNA level) in the disappearance of the cryoglobulins or the improvement in cryoglobulin related symptoms was also evaluated.

Abbreviations used in this paper: $\mathrm{HCV}$, hepatitis $\mathrm{C}$ virus; ALT, alanine aminotransferase; RT, reverse transcription; PCR, polymerase chain reaction. 


\section{Patients and methods PATIENTS}

From 1990 to 1994 , at the hepatology and internal medicine units of Pitié-Salpêtrière Hospital, Paris, France, we recruited 87 consecutive patients ( 40 women and 47 men; age range $26-82$ years, median 49 years) with chronic hepatitis $\mathrm{C}$ treated for the first time with interferon $\alpha$. All of them had completed six months of interferon treatment. The diagnosis of hepatitis C was based on the usual criteria-that is, ALT levels more than 1.5 times the upper limit of the normal range for more than six months, presence of anti-HCV antibody, and HCV RNA detected in serum by reverse transcription (RT) nested polymerase chain reaction (PCR). Patients with HIV or hepatitis B virus infection, cancer, haemopathy, lymphoma, hepatocellular carcinoma, decompensated liver cirrhosis, bacterial or parasitic infection, autoimmune diseases, or autoantibodies >1:200 (anti-nuclear, antimitochondrial, and anti-smooth muscle) detected by immunofluorescence ${ }^{22} 23$ were excluded. The following epidemiological variables were recorded in each case: age, sex, and duration of infection (from the date of infection, when known). We also recorded the presence of clinical manifestations associated with cryoglobulins, including arthralgia, cutaneous involvement such as purpura, vasculitis, Raynaud's phenomenom, renal abnormalities, and peripheral neuropathy. Biochemical and immunological variables were also determined in each case. Serum levels of ALT, aspartate aminotransferase, total bilirubin, $\gamma$-globulins, and rheumatoid factor and haematological variables were assayed by standard procedures before the treatment, every month during the treatment, and six months after the end of treatment.

DETECTION, ISOLATION, AND CHARACTERISATION OF CRYOGLOBULINS AND RHEUMATOID FACTOR Cryoglobulinaemia was detected, quantified, and typed as previously described. ${ }^{24}$ Briefly, cryoglobulins were precipitated and stored for up to seven days $\left(4^{\circ} \mathrm{C}, 0.1 \mathrm{~g} / 1\right.$ sodium azide). The precipitates were washed five times at $4^{\circ} \mathrm{C}$ with $0.15 \mathrm{~mol} / 1 \mathrm{NaCl}$, and the total protein concentration was measured by reading the absorbance at $280 \mathrm{~nm}$. A purified human $\gamma$-globulin preparation (Centre National de Transfusion Sanguine, Paris, France) was used as standard. Patients were diagnosed as having cryoglobulins if their serum cryoglobulin level was higher than $0.05 \mathrm{~g} / 1$ on two consecutive occasions. The immunoglobulin composition of the washed cryoglobulins was determined by western blotting as described by Musset et al. ${ }^{24}$ Rheumatoid factor was detected using the Rhumalatex agglutination test (Fumouze, Asnières, France). Serum dilutions above 1:160 were considered positive.

VIROLOGICAL METHODS

Detection of serum anti-HCV antibodies

Anti-HCV antibodies were detected by a second or third generation enzyme linked immunosorbent assay (ELISA) and recom- binant immunoblot assay (RIBA) (Ortho Diagnostic Systems, Raritan, New Jersey, USA).

Qualitative detection of HCV RNA

All the patients were tested for HCV RNA in the serum using an RT nested PCR, as previously described, ${ }^{10}$ before treatment, at the end of treatment, and six months after the end of treatment.

\section{Quantitative detection of HCV RNA}

Serum HCV RNA level was determined before treatment in all patients, by using the quantitative branched DNA signal amplification assay (Quantiplex 1.0; Chiron Corporation, Emeryville, California, USA). The branched DNA is based on specific hybridisation of synthetic oligonucleotides located in the 5' untranslated region of the $\mathrm{HCV}$ genome. The detection limit is $3.5 \times 10^{5}$ genome equivalents $/ \mathrm{ml}^{25}$

In 18 patients with cryoglobulins (10 with symptoms compatible with cryoglobulinaemia and eight without symptoms), we also measured the level of HCV RNA in the purified cryoprecipitate. The cryoglobulin precipitates were diluted at $37^{\circ} \mathrm{C}$ to a total protein concentration identical with those in the corresponding sera.

\section{Genotyping}

All the samples were genotyped by using the first generation Line Probe Assay (LiPA; Innogenetics, Antwerp, Belgium). ${ }^{26}$ The current LiPA can be used to type and subtype the most common genotypes: $1 \mathrm{a}, 1 \mathrm{~b}, 2 \mathrm{a}, 2 \mathrm{~b}, 3 \mathrm{a}, 4$, and 5 .

HISTOLOGICAL ANALYSIS

Liver biopsy was performed in every case before treatment. The severity of the histological lesions was assessed by using the Knodell score. ${ }^{27}$ Results of histological analysis were available after treatment for 42 patients. Most patients who did not have a liver biopsy after treatment had normalised ALT levels during treatment.

TREATMENT SCHEDULE

All patients received recombinant interferon $\alpha$ 2a (Roferon-A; Hoffmann-La Roche, Basel, Switzerland) or 2b (Intron-A; Schering Plough, Bloomfield, New Jersey, USA) for the first time, at a dose of $3 \times 10^{6}$ IU intramuscularly three times a week for six months. All the patients gave their informed consent to participate in the study and the protocol was approved by the local ethics committees.

EVALUATION OF THE THERAPEUTIC RESPONSE We defined three types of response to interferon on the basis of biochemical, virological, and immunological variables.

At the end of interferon treatment

Patients with normal serum ALT levels were considered to have a biochemical response, those with undetectable HCV RNA were 
Table 1 Characteristics of patients with (group 1) and without (group 2) cryogblobulins before treatment

\begin{tabular}{llll}
\hline & Group 1 $(n=43)$ & Group 2 $(n=44)$ & $p$ Value \\
\hline Age (years) & $52(13)$ & $46(13)$ & 0.1 \\
Sex (M/F) & $19 / 24$ & $28 / 16$ & 0.033 \\
ALT ( $\times$ ULNR) & $2.9(1.5)$ & $3.5(2.9)$ & 0.3 \\
Duration of LD (years) & $18(11)$ & $12.5(9.5)$ & 0.02 \\
Cirrhosis (\%) & 39.5 & 20 & 0.028 \\
Knodell score & $8.83(2.5)$ & $7.93(2.7)$ & 0.1 \\
Cryoglobulin type II/III (\%) & $44 / 56$ & - & - \\
Cryoglobulin concentration (g/l) & $0.30(0.40)$ & - & - \\
Presence of RF $(\%)$ & 70 & 9 & 0.0001 \\
Viral load $\left(\times 10^{5}\right.$ eq/ml) & $52(51)$ & $52(70)$ & 0.1 \\
Genotype 1 $(\%)$ & 63 & 57 &
\end{tabular}

Where applicable, values are expressed as mean (SD).

ALT, alanine aminotransferase; ULNR, upper limit of normal range; LD, liver disease; RF, rheumatoid factor.

Table 2 Characteristics of patients with cryoglobulinaemia before treatment

\begin{tabular}{llll}
\hline & $\begin{array}{l}\text { Patients with } \\
\text { symptoms }(n=12)\end{array}$ & $\begin{array}{l}\text { Patients without } \\
\text { symptoms }(n=31)\end{array}$ & $p$ Value \\
\hline Age (years) & $55(10)$ & $50(13)$ & 0.20 \\
Sex (M/F) & $5 / 7$ & $14 / 17$ & 0.26 \\
ALT $(\times$ ULNR) & $2.6(1.2)$ & $3.2(1.6)$ & 0.2 \\
Duration of LD (years) & $22.5(10.5)$ & $15.5(11.5)$ & 0.69 \\
Cirrhosis (\%) & 25 & 45 & 0.14 \\
Knodell score & $8(2)$ & $9.1(2.6)$ & 0.20 \\
Cryoglobulin type II/III (\%) & $50 / 50$ & $42 / 58$ & 0.24 \\
Cryoglobulin concentration (g/l) & $0.49(0.43)$ & $0.20(0.13)$ & 0.01 \\
Presence of $\mathrm{RF}(\%)$ & 92 & 61 & 0.046 \\
Viral load $\left(\times 10^{5}\right.$ eq/ml) & $51(67)$ & $52(47)$ & 0.9 \\
Genotype $1(\%)$ & 70 & 61 & 0.26 \\
\hline
\end{tabular}

Where applicable, values are mean (SD).

ALT, alanine aminotransferase; ULNR, upper limit of normal range; LD, liver disease; RF, rheumatoid factor.

considered to have a virological response, and those in whom cryoglobulins had disappeared were defined as having an immunological response. Patients in whom ALT activity did not normalise during treatment were defined as non-responders.

Six months after the end of interferon treatment Patients in whom ALT levels remained normal were defined as having a sustained biochemical response, those in whom HCV RNA was still undetectable were defined as having a sustained virological response, and those in whom cryoglobulins remained undetectable were considered to have a sustained immunological response. Biochemical relapse was defined as a "re-increase" in ALT activity after the end of treatment, virological relapse as re-emergence of HCV RNA, and immunological relapse as re-emergence of cryoglobulins.

The outcome of clinical manifestations related to cryoglobulins was also studied during and after treatment. Rheumatoid factor activity during treatment was also evaluated.

\section{STATISTICAL ANALYSIS}

Differences between proportions were assessed by using the $\chi^{2}$ method or Fisher's exact test. Mean quantitative values were compared using Student's $t$ test. An unconditional logistic regression was performed using SAS software 6.0 release. Results are expressed as mean (SD), conditional odds ratio, and 95\% confidence interval.

\section{Results}

CHARACTERISTICS OF PATIENTS BEFORE

TREATMENT

Table 1 shows the epidemiological, clinical, and virological characteristics of the patients. Of the 87 patients with chronic hepatitis C, 43 (49\%) had mixed cryoglobulinaemia (group 1) and $44(51 \%)$ did not (group 2). As shown previously, ${ }^{10} 27$ cirrhosis was more frequent in group 1 and the known duration of hepatitis was longer in this group. Rheumatoid factor was detected in a significantly higher percentage of cases in group 1 than in group $2(70 \% v$ $9 \%$ respectively, $p<0.0001)$. The percentage of women was significantly higher among the cryoglobulin positive patients. The distribution of HCV genotypes was not significantly different between the two groups (group 1:1a $=10 \% ; 1 \mathrm{~b}$ $=53 \% ; 2 \mathrm{a} / 2 \mathrm{c}=19 \% ; 3=13 \% ; 4$ or $5=5 \%$; group $2: 1 \mathrm{a}=15 \% ; 1 \mathrm{~b}=42 \% ; 2=28 \% ; 3=$ $10 \% ; 4$ or $5=5 \%)$. The level of viraemia before treatment was similar in patients with and without cryoglobulins.

Of the 43 patients with cryoglobulins, 19 (44\%) had type II and 24 (56\%) type III (NS). Patients with type II or type III cryoglobulins had similar epidemiological, biochemical, and virological features. As previously reported, ${ }^{10} 27$ cirrhosis was found more frequently in patients with type II cryoglobulins than in those with type III $(58 \%$ v $25 \%, \mathrm{p}=0.03)$. Twelve patients $(28 \%)$ had cryoglobulin related extrahepatic symptoms of variable severity: four had purpura, five had other cutaneous signs (Raynaud's phenomenon or legs ulcers), six had arthralgia, two had glomerulonephritis, and six had peripheral neuropathy. The cryoglobulin level and the presence of rheumatoid factor was significantly higher in these patients than in asymptomatic ones. The percentage of patients with type II $v$ type III was similar among symptomatic and asymptomatic patients, but the mean cryoglobulin level before treatment was higher in the former. The mean concentration of HCV RNA in the cryoprecipitate of the 10 patients with symptoms compatible with cryoglobulinaemia was higher than in the cryoprecipitate of the eight patients without symptoms (2800 (6000)-fold higher in the cryoprecipitate than in the sera compared with 361 (400)-fold higher), but not significantly.

The severity of the liver disease assessed by the Knodell score was not significantly different between symptomatic and asymptomatic patients (table 2).

\section{RESPONSE TO INTERFERON}

Table 3 shows the responses to interferon therapy (at the end of treatment and six months after the end of treatment).

Liver biopsies were performed in 42 patients (eight sustained virological responders, 12 relapsers, and 22 non-responders) after the interferon treatment. The Knodell score had decreased significantly after treatment (8.6 (2.72) to 6.38 (2.73), $\mathrm{p}=0.004)$. When comparing the Knodell score before and after treatment, we observed a significant decrease in sustained responders (10 (3.1) v 5.25 (2.49), p $=0.006)$ and in relapsers (8.42 (3.3) $v 5.92$ 
Table 3 Response to interferon (IFN) in patients with (group 1) and without (group 2) cryoglobulins

\begin{tabular}{|c|c|c|c|c|}
\hline & $\begin{array}{l}\text { Group } 1 \\
(n=43)\end{array}$ & $\begin{array}{l}\text { Group } 2 \\
(n=44)\end{array}$ & $\begin{array}{l}\text { Total } \\
(n=87)\end{array}$ & $p$ Value \\
\hline \multicolumn{5}{|l|}{ At the end of IFN } \\
\hline Biochemical response & $27(63)$ & $23(52)$ & $50(57)$ & NS \\
\hline Virological response & $18(42)$ & $12(27)$ & $30(34)$ & NS \\
\hline Immunological response & $17(40)$ & - & $17(40)$ & NS \\
\hline $\begin{array}{l}\text { Virological response and } \\
\text { immunological response }\end{array}$ & $12(28)$ & - & $12(28)$ & NS \\
\hline \multicolumn{5}{|l|}{ After the end of IFN } \\
\hline Sustained biochemical response & $9(21)$ & $9(21)$ & $18(21)$ & NS \\
\hline Sustained virological response & $6(14)$ & $8(18)$ & $15(18)$ & NS \\
\hline Sustained immunological response & $6(14)$ & - & $6(14)$ & NS \\
\hline $\begin{array}{l}\text { Sustained virological response and } \\
\text { immunological response }\end{array}$ & $6(14)$ & - & $6(14)$ & NS \\
\hline
\end{tabular}

The values in parentheses are percentages.

Table 4 Response to interferon (IFN) in symptomatic and asymptomatic patients with cryoglobulins

\begin{tabular}{llll}
\hline & \multicolumn{2}{l}{ Patients with cryoglobulins $(n=43)$} & \\
\cline { 2 - 3 } & $\begin{array}{l}\text { Asymptomatic } \\
(n=31)\end{array}$ & $\begin{array}{l}\text { Symptomatic } \\
(n=12)\end{array}$ & p Value \\
\hline At the end of IFN & & & \\
$\quad$ Biochemical response & $22(71)$ & $5(42)$ & 0.1 \\
$\quad$ Virological response & $14(45)$ & $4(33)$ & 0.2 \\
$\quad$ Immunological response & $15(48)$ & $2(17)$ & 0.08 \\
$\quad \begin{array}{l}\text { Virological response and immunological } \\
\text { response }\end{array}$ & $11(35)$ & $1(8)$ & 0.1 \\
$\quad$ No response & $9(29)$ & $7(58)$ & 0.1 \\
After the end of IFN & $7(22)$ & $2(17)$ & 0.7 \\
$\quad \begin{array}{l}\text { Sustained biochemical response } \\
\text { Sustained virological response }\end{array}$ & $5(16)$ & $2(17)$ & 0.5 \\
$\quad \begin{array}{l}\text { Sustained immunological response } \\
\quad \text { Sustained virological response and }\end{array}$ & $5(16)$ & $1(8)$ & 0.6 \\
immunological response & $5(16)$ & $1(8)$ & 0.6 \\
\hline
\end{tabular}

The values in parentheses are percentages.

Table 5 Improvement in clinical manifestations linked to cryoglobulinaemia in patients treated with interferon

\begin{tabular}{lll}
\hline $\begin{array}{l}\text { Clinical manifestations before } \\
\text { interferon }\end{array}$ & $\begin{array}{l}\text { Improvement } \\
\text { at the end of } \\
\text { interferon }\end{array}$ & Improvement six months after interferon withdrawal \\
\hline $\begin{array}{lll}\text { Purpura }(\mathrm{n}=4) \\
\text { Arthralgia }(\mathrm{n}=6)\end{array}$ & $\mathrm{n}=4$ & $\mathrm{n}=1$ sustained virological responder \\
& $\mathrm{n}=4$ & $\begin{array}{l}\mathrm{n}=3 \text { (1 sustained virological responder; } 2 \\
\text { relapsers) }\end{array}$ \\
Other cutaneous signs $(\mathrm{n}=5)$ & $\mathrm{n}=2$ & $\mathrm{n}=1$ (sustained virological responder) \\
$\begin{array}{l}\text { Glomerulonephritis }(\mathrm{n}=2) \\
\text { Neuropathy }(\mathrm{n}=6)\end{array}$ & $\mathrm{n}=0$ & $\mathrm{n}=0$ \\
\hline
\end{tabular}

(3.28), $\mathrm{p}=0.049)$, but not in the nonresponders $(7.91(2.22) v 7.05(2.4), \mathrm{p}=0.11)$. We did not compare patients with or without cryoglobulins, because liver biopsies were not performed in a similar percentage of responders, relapsers, and non-responders in the two groups.

PATIENTS WITH CRYOGLOBULINS (TABLE 3)

At the end of interferon therapy

The decrease in the cryoglobulin level was significantly greater in patients showing a virological response than in the others $(p=0.013)$, and the clearance of cryoglobulins was associated with the loss of HCV RNA in $12(71 \%)$ of the 17 patients. In nine patients $(21 \%)$, the initial cryoglobulin level was reduced by more than $50 \%$. Six of them had normal ALT levels and two had undetectable HCV RNA.

Six months after the end of interferon treatment Nine patients $(21 \%)$ had a sustained biochemical response and the other relapsed. A sustained virological response was observed in seven patients (16\%). Cryoglobulins reappeared in 11 patients with an initial immunological response. Among the nine patients with an initial reduction in the cryoglobulin level of more than $50 \%$, the cryoglobulin level stabilised in six (66\%) and increased in two. Finally, six (14\%) patients, all of whom also had a sustained virological response, had a sustained immunological response.

\section{COMPARISON BETWEEN PATIENTS WITH AND} WITHOUT CRYOGLOBULIN RELATED SYNDROME (TABLE 4)

At the end of interferon treatment

As shown in table 4, the response to interferon was not significantly different between the patients with and without clinical symptoms, although the immunological response appears to be higher in patients without symptoms (48\% v 16\%, $\mathrm{p}=0.08)$, but not significantly. The disappearance of cryoglobulins was associated with the disappearance of HCV RNA in only one symptomatic patient compared with 11 asymptomatic patients $(\mathrm{p}=0.1, \mathrm{NS})$. Clinically, an improvement in purpura was observed in four patients (three had normal ALT levels and one had a virological response). Two other patients showed an improvement in other cutaneous signs (one had a biochemical and virological response but the other did not). No clinical improvement was observed in the six patients with neurological manifestations before treatment (table 5).

Six months after the end of interferon treatment As shown in table 4, the percentage of patients with a sustained response to interferon was not significantly different between the two groups. Among the symptomatic patients, only two $(17 \%)$ had a sustained biochemical and virological response, associated with a sustained clearance of cryoglobulins in only one case $(8 \%)$. All five asymptomatic patients who exhibited a sustained biochemical response and a virological response also had a sustained immunological response. The cryoglobulin level was significantly lower in patients with a sustained virological response than in those without, among the asymptomatic patients (undetectable $v 0.18(0.12) \mathrm{g} / \mathrm{l}, \mathrm{p}=0.003)$, but not among the symptomatic ones $(0.51(0.57)$ v $0.40(0.57) \mathrm{g} / \mathrm{l}, \mathrm{p}=0.82$ ) (fig 1 ). All other patients had a biochemical, virological, and/or immunological relapse. Purpura was still absent in the two patients with both a sustained biochemical response and virological response but reappeared in the other patients (table 5). Late improvement in peripheral neuropathy was never observed.

FACTORS PREDICTIVE OF THE RESPONSE TO INTERFERON

Univariate analysis (table 6) indicated that patients with a sustained virological response were more often men, infected with genotype 2 or 3, and had a lower pretreatment viral load. In patients with cryoglobulins, the main predictive factors of response were the sex (male, $\mathrm{p}=0.003$ ) and infection with genotype 2 or $3(p=0.008)$. All patients without cryoglobulins showing a sustained virological 


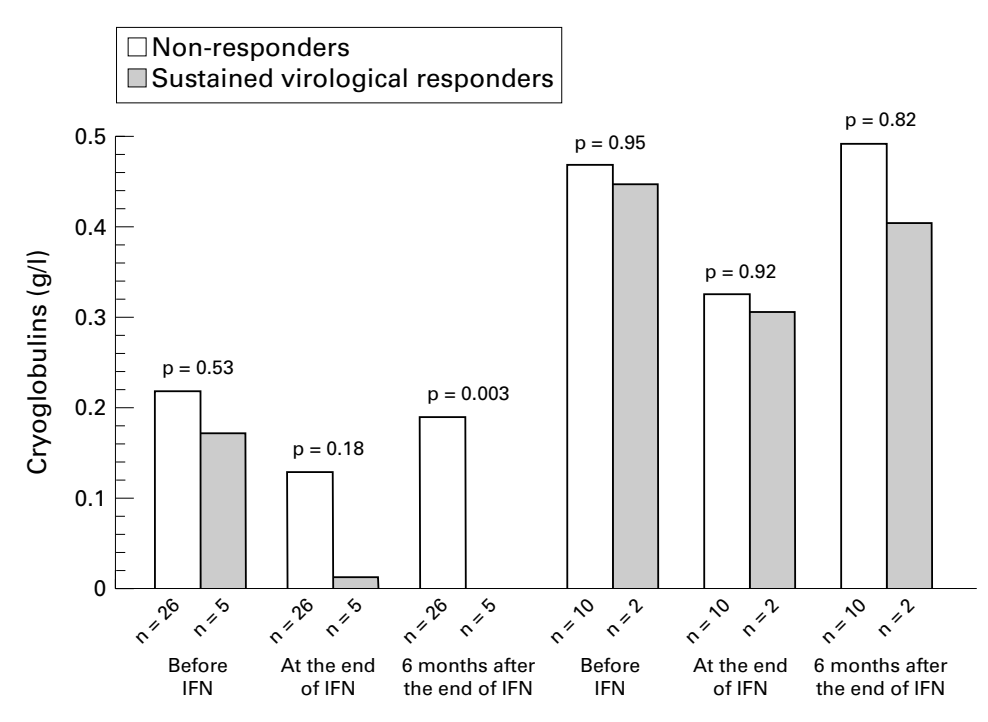

Asymptomatic patients

Symptomatic patients

Figure 1 Comparison of the cryoglobulin concentration before and at the end of interferon (IFN) treatment and six months after the end, in accordance with sustained virological response, in patients with and without cryoglobulinaemia related symptoms.

response were infected with genotype 2 or 3 , and this was the main predictive factor of good response for this group.

We used a multivariate logistic regression to analyse pretreatment variables independently associated with a sustained virological response. These variables were age, sex, duration of liver disease, presence of cryoglobulinaemia, presence of cirrhosis, pretreatment level of cryoglobulins, and HCV genotypes. Level of viraemia was not included in the multivariate model because viraemia was the criterion used to define the response and the pretreatment viral load was highly associated with the virological response. The gender (male) and infection with genotype 2 or 3 were identified as independent variables associated with a sustained virological response. As the variable genotype 1 appeared to be strongly associated with no response (none of the patients infected with genotype 1 had a sustained virological response), we analysed the same variables in patients infected with genotype 2 or 3 only. We found that gender (male) was also an independent factor of sustained virological response to interferon. Whatever the analysis used, the presence of cryoglobulins never appeared to be a predictive factor of response to interferon.

\section{Discussion}

In 1987 Bonomo et $a l^{16}$ treated seven patients with type II idiopathic mixed cryoglobulinaemia with recombinant interferon $\alpha$ and obtained a remarkable clinical improvement together with a reduction in circulating cryoglobulins in every case. Several authors have since studied the effect of interferon on cryoglobulinaemia. Casato et $a l^{17}{ }^{18}$ reported a response rate of $77 \%$ and $62 \%$ in patients with symptomatic cryoglobulins treated with interferon, but long term remission was observed in only $10 \%$ of cases. Ferri et al ${ }^{19}$ treated 26 patients with mixed cryoglobulinaemia associated with $\mathrm{HCV}$ infection. They obtained an improvement in cryoglobulin related clinical manifestations and in the cryoglobulin level in $73 \%$ of the patients, but HCV RNA became undetectable in only $15 \%$ of patients and all relapsed when interferon treatment was stopped. In 1994, Misiani et $a l^{20}$ performed a controlled study involving 53 patients with $\mathrm{HCV}$ associated type II severe symptomatic cryoglobulinaemia. Among the 27 patients treated with $3 \times 10^{6} \mathrm{IU}$ interferon three times a week, HCV RNA disappeared in $60 \%$. Clinical and immunological manifestations improved only in patients in whom HCV RNA disappeared. However, all of them had a virological relapse after interferon was discontinued, followed by a recurrence or exacerbation of symptoms. Dammacco et $a l^{11}$ compared the efficiency of interferon $\alpha$ alone with that of a combination of interferon $\alpha$ and 6-methylprednisolone in 65 patients with mixed cryoglobulinaemia. The virological and clinical response rates were similar in the two groups, even if relapses occurred three to six months later in patients who received the combination.

In this study, we compared the response to interferon in patients with chronic HCV infection, with or without cryoglobulins, all of whom were receiving interferon for the first time, and examined the relation between the response to interferon therapy and the disappearance of cryoglobulinaemia. The response rate was similar to that observed in other studies, ${ }^{12-152930}$ with normalisation of ALT levels in $57 \%$ of cases at the end of interferon therapy. However, HCV RNA disappeared in only $34 \%$ of cases, probably because we used a low dose of interferon $\alpha\left(3 \times 10^{6} \mathrm{IU}\right.$ three times a week) and a high percentage of patients were

Table 6 Predictive factors of sustained virological response to interferon (univariate analysis)

\begin{tabular}{|c|c|c|c|c|c|c|c|c|}
\hline & \multicolumn{4}{|c|}{ Patients with and without cryoglobulins $(n=87)$} & \multicolumn{4}{|c|}{ Patients with cryoglobulins $(n=43)$} \\
\hline & $\begin{array}{l}\text { Sustained VR } \\
(n=15)\end{array}$ & $p$ & $O R$ & $C I$ & $\begin{array}{l}\text { Sustained VR } \\
(n=7)\end{array}$ & $p$ & $O R$ & $C I$ \\
\hline Age (years) & $52(16)$ & 0.5 & - & - & $56(15)$ & 0.8 & - & - \\
\hline $\operatorname{Sex}(\% \mathrm{M})$ & 87 & 0.008 & 5.53 & $1.7-19$ & 86 & 0.032 & 7.57 & $1-40$ \\
\hline Cirrhosis $(\%)$ & 13 & 0.12 & - & - & 14 & 0.21 & - & - \\
\hline Duration of LD (years) & $11(8)$ & 0.25 & - & - & $10(7)$ & 0.07 & - & - \\
\hline Presence of Cgs (\%) & 47 & 0.81 & - & - & - & - & - & - \\
\hline Cryoglobulin concentration before IFN (g/1) & $0.30(0.23)$ & 0.78 & - & - & $0.30(0.23)$ & 0.78 & - & - \\
\hline Viral load $\left(\times 10^{5} \mathrm{eg} / \mathrm{ml}\right)$ & $21(30)$ & 0.022 & - & - & $31(35)$ & 0.9 & - & - \\
\hline Genotype 2 or $3(\%)$ & 93 & 0.001 & 24 & $7-85$ & 83 & 0.008 & 10.8 & $2-53$ \\
\hline
\end{tabular}

Where applicable, values are expressed as mean (SD).

$\mathrm{VR}$, virological responder; OR, odds ratio; CI, confidence interval; LD, liver disease; IFN, interferon. 
infected by genotype 1 or because our RT nested PCR is more sensitive than the technique used in other studies. ${ }^{31}$

We found that the rate of sustained responses was similar in patients with and without cryoglobulins, suggesting that cryoglobulins do not significantly influence the outcome of interferon therapy. Cryoglobulins disappeared or levels fell in $60 \%$ of patients, and this was accompanied by disappearance of HCV RNA in $54 \%$ of cases. However, sustained responses, with disappearance of both cryoglobulins and HCV RNA, were obtained in only $14 \%$ of patients six months after interferon withdrawal. All of the patients who still had undetectable cryoglobulins also had undetectable $\mathrm{HCV}$ RNA, showing that clearance of cryoglobulins is closely related to the disappearence of the HCV RNA and that the efficiency of interferon $\alpha$ treatment of cryoglobulinaemia associated with HCV infection is mainly due to its antiviral activity. Several authors including our group ${ }^{810}$ have shown that cryoprecipitates contain high concentrations of HCV RNA, antiHCV antibodies, and HCV proteins. The lowering of viraemia may decrease the amount of circulating virions and immune complexesthat is cryoglobulins - and thereby improve clinical manifestations. Unfortunately, interferon withdrawal was generally followed by a clinical relapse and a rise in cryoglobulin levels, usually associated with the reappearance of HCV RNA in the serum.

In the 12 patients with clinical manifestations of cryoglobulins, the response was poorer (tables 4 and 5), especially in those with neuropathies. Purpura improved or disappeared in all the treated patients while other cutaneous signs improved principally in the patients who responded, as reported by others. ${ }^{17-20}$ We did not find any statistical difference in epidemiological or virological features between patients with and without symptoms, in particular neuropathies, to explain such discrepant response rates. We have previously shown ${ }^{10}$ that patients with clinical manifestations generally have higher serum levels of cryoglobulins, and moreover these cryoglobulins contain higher amounts of HCV RNA than the corresponding sera. In the present study, the concentration of HCV RNA tended to be higher in the cryoprecipitates of patients with symptoms than in those without symptoms but the difference was not significant, because of the wide range of HCV RNA levels and the small number of patients studied. Thus the true level of viraemia may be underestimated, and patients with symptoms may in fact have higher HCV RNA levels, as suggested, ${ }^{32}$ and this could explain the smaller response to interferon.

We also analysed predictive factors of the response to interferon in patients with or without cryoglobulins. In both groups, a sustained virological response to interferon was associated with viral load and infection by genotype 2 or 3 , as recently suggested. ${ }^{29}{ }^{30}$ In contrast with other studies in which the sex factor was not predictive of response to treatment, ${ }^{29}{ }^{30}$ or in which female gender was associated with a higher response rate, ${ }^{33}$ we found that male gender was more often associated with a sustained response. In the present study, genotype 1 was predominant in the female group, and this may explain the lower rate of sustained response in this group.

In conclusion, this study suggests that presence of cryoglobulins does not significantly worsen the response to interferon therapy in patients with chronic hepatitis $\mathrm{C}$ without clinical manifestations. In these patients, a sustained disappearance of cryoglobulins correlates highly with disappearance of HCV RNA. However, we also found that patients with severe clinical manifestations of cryoglobulinaemia - that is, neuropathy-do not usually respond to interferon at the classic dosage. In our experience, interferon treatment given earlier, at higher dosage and longer and/or combination with ribavirin, may benefit patients with severe clinical manifestations of cryoglobulinaemia - that is, neuropathythose infected by genotype 1 , and those with a high pretreatment viral load. A multicentre study should be encouraged, to assess the efficiency of combination therapy or new therapeutic strategies in large series of cryoglobulinaemic patients.

This work was supported in part by grants from the Association pour la Recherche contre le Cancer (ARC).

1 Meltzer M, Elias K, McCluskey RT, et al. Cryoglobulinemia: a clinical and laboratory study. Am f Med 1966;40:837-56. 2 Gorevic P, Kassab H, Levo Y, et al. Mixed cryoglobulinemia: clinical aspects and long-term follow-up of 40 patients. $\mathrm{Am}$ f Med 1980;69:287-308.

3 Brouet JC, Clauvel JP, Danon F, et al. Biologic and clinical significance of cryoglobulins. Am $\mathcal{F}$ Med 1974;57:775-88.

4 Levo Y, Gorevic PD, Hanna MD, et al. Liver involvement in the syndrome of mixed cryoglobulinemia. Ann Intern Med 1977;87:287-92.

5 Pascual M, Perrin L, Giostra E, et al. Hepatitis C virus in patients with cryoglobulinemia type II. F Infect Dis 1990;162:569-70.

6 Zarski JP, Rougier D, Aubert H, et al. Association cryoglobuline et maladie hépatique: fréquence, nature et caractères immuno-chimiques de la cryoglobulinémie. Gastroenterol Clin Biol 1984;8:845-50.

7 Ferri C, Greco F, Longombardo G, et al. Antibodies to hepatitis $C$ virus in patients with mixed cryoglobulinemia. hepatitis C virus in patients with
Arthritis Rheum 1991;34:1606-10.

8 Agnello V, Chung RT, Kaplan LM. A role for hepatitis C virus infection in type II cryoglobulinemia. $N$ Engl $f \mathrm{Med}$ 992;327:1490-5.

9 Cacoub P, Lunel F, Musset L, et al. Hepatitis C virus and cryoglobulinemia. N Engl $\mathcal{F}$ Med 1993;328:1121-2.

10 Lunel F, Musset L, Cacoub P, et al. Cryoglobulinemia in chronic liver diseases: role of hepatitis $\mathrm{C}$ virus and liver damage. Gastroenterology 1994;106:1291-300.

11 Agnello V. Hepatitis C virus infection and type II cryoglobulinemia: an immunological perspective. Hepatology 1997;26:1375-9.

12 Hoofnagle JH, Mullen KD, Jones DB, et al. Treatment of chronic Non-A, Non-B hepatitis with recombinant human alpha interferon. A preliminary report. $N$ Engl F Med 1986; 315:1575-8.

13 Di Bisceglie AM, Martin P, Kassianides C, et al. Recombinant interferon alfa therapy for chronic hepatitis C. A binant interferon alfa therapy for chronic hepatitis C. A
randomized, double-blind, placebo-controlled trial. $N$ Engl randomized, double-blind,

14 Davis GL, Balart LA, Schiff ER, et al Treatment of chronic hepatitis $\mathrm{C}$ with recombinant interferon alfa: a multicenter randomized, controlled trial. $N$ Engl f Med 1989;321: 1501-6

15 Marcellin P, Boyer N, Giostra E, et al. Recombinant human alpha-interferon in patients with chronic Non-A Non-B hepatitis: a multicenter randomized controlled trial from France. Hepatology 1991;13:393-7.

16 Bonomo L, Casato M, Afeltra A, et al. Treatment of idiopathic mixed cryoglobulinemia with alpha interferon. Am $\mathcal{F}$ Med 1987;83:726-30.

17 Casato M, Lagana B, Antonelli G, et al. Long-term results of therapy with Interferon-alpha for type II essential mixed herapy with Interferon-alpha for type

18 Casato M, Agnello V, Pucillo LP, et al. Predictors of long-term response to high-dose interferon therapy in type II cryoglobulinemia associated with hepatitis virus C infection. Blood 1997;90:3865-73. 
19 Ferri C, Marzo M, Longombardo G, et al. Interferon alfa in mixed cryoglobulinemia patients: a randomized, crossovermixed cryoglobulinemia patients: a rand

20 Misiani R, Bellavita P, Fenili D, et al. Interferon alfa-2a therapy in cryoglobulinemia associated with hepatitis $\mathrm{C}$ virus. $N$ Engl f Med 1994;330:751-6.

21 Dammacco F, Sansonno D, Han JH, et al. Natural interferon alfa versus its combination with 6-methylprednisolone on the therapy of type II mixed cryoglobulinemia: a long-term, randomized, controlled study. Blood 1994;84:3336-43.

22 Homberg JC, Abuaf N, Bernard O, et al. Chronic active hepatitis associated with anti-liver/kidney microsome antibody type 1: a second type of "autoimmune" hepatitis. Hepatology 1987;7:1333-9.

23 Martini E, Abuaf N, Cavalli F, et al. Antibody to liver cytosol (anti-LC1) in patients with autoimmune chronic active hepatitis type 2. Hepatology 1988;8:1662-6.

24 Musset L, Diemert MC, Taibi F, et al. Characterization of cryoglobulins by immunoblotting. Clin Chem 1992;38:798802 .

25 Urdea MS, Horn T, Fulz TJ, et al. Branched DNA amplification multimers for the sensitive direct detection of human hepatitis viruses. Nucleic Acids Research Symposia and Seminars 1991;24:197-200.

26 Stuyver L, Rossau R, Wyseru A, et al. Typing of hepatitis C virus isolates and characterization of new subtypes using a line probe assay. F Gen Virol 1993;74:1093-102.
27 Knodell RG, Ishak KG, Black WC, et al. Formulation and application of a numerical scoring system for assessing histological activity in asymptomatic chronic active hepatitis. Hepatology 1981;1:431-5.

28 Frangeul L, Musset L, Cresta P, et al. Hepatitis C virus genotypes and subtypes in patients with hepatitis C, with and without cryoglobulinemia. 7 Hepatol 1996;25:427-32.

29 Martinot-Peignoux M, Marcellin P, Pouteau M, et al. Pretreatment serum hepatitis $\mathrm{C}$ virus RNA levels and hepatitis $\mathrm{C}$ irus genotype are main and independent prognostic factors of sustained response to interferon alfa

30 Chemello L, Cavalletto L, Noventa F, et al. Predictors of sustained response, relapse and no response in patients with chronic hepatitis $\mathrm{C}$ treated with interferon alfa. $\mathcal{F}$ Viral Hepatitis 1995;2:91-6.

31 Lunel F, Cresta P, Vitour D, et al. Comparative evaluation of hepatitis C virus RNA quantitation by branched DNA, NASBA, and monitor assays. Hepatology 1999;29:528-35.

32 Van Thiel DH, Fagiuoli S, Caraceni P, et al. Cryoglobulinemia: a cause for false negative polymerase chain reaction results in patients with hepatitis $\mathrm{C}$ virus positive chronic liver disease. F Hepatol 1995;22:464-7.

33 Causse X, Godinot H, Chevallier M, et al. Comparison of 1 Causse $\mathrm{X}$, Godinot $\mathrm{H}$, Chevallier $\mathrm{M}$, et al. Comparison of 1
or $3 \mathrm{MU}$ of interferon alfa-2b and placebo in patients with chronic non-A, non-B hepatitis. Gastroenterology 1991;101: 497-502. 